\title{
Can we improve outcomes in AF patients by early therapy? Paulus Kirchhof ${ }^{1,2}$
}

Address: ${ }^{1}$ Department of Cardiology and Angiology, University Hospital Münster, Germany and ${ }^{2}$ German Atrial Fibrillation competence NETwork (AFNET)

Email: Paulus Kirchhof - kirchhp@uni-muenster.de

Published: 26 November 2009

BMC Medicine 2009, 7:72 doi:10.1186/1741-7015-7-72

This article is available from: http://www.biomedcentral.com/I74/-70/5/7/72

(C) 2009 Kirchhof; licensee BioMed Central Ltd.

This is an Open Access article distributed under the terms of the Creative Commons Attribution License (http://creativecommons.org/licenses/by/2.0), which permits unrestricted use, distribution, and reproduction in any medium, provided the original work is properly cited.

\begin{abstract}
Atrial fibrillation affects at least $1 \%$ of the population and causes marked society-wide morbidity and mortality. Current management of atrial fibrillation including antithrombotic therapy and management of concomitant conditions in all patients, rate control therapy in most patients, and rhythm control therapy in patients with severe atrial fibrillation-related symptoms can alleviate atrial fibrillation-related symptoms but can neither effectively prevent recurrent atrial fibrillation nor suppress atrial fibrillation-related complications. Hence, there is a need for better therapy of atrial fibrillation.

The etiology of atrial fibrillation is complex. Most of the causes of atrial fibrillation which are known at present perpetuate themselves in vicious circles, and presence of the arrhythmia by itself causes marked damage of atrial myocardium. These pathophysiological insights suggest that early diagnosis and comprehensive therapy of atrial fibrillation, including adequate therapy of all atrial fibrillationcausing conditions, rate control, and rhythm control therapy, could help to prevent progression of atrial fibrillation and reduce atrial fibrillation-related complications. Such a therapy should make use of safe and effective therapeutic modalities, some of which have become available recently or will become available in the near future. The hypothesis that early diagnosis and early, comprehensive therapy of atrial fibrillation can improve outcomes requires formal testing in controlled trials.
\end{abstract}

\section{Commentary}

Atrial fibrillation (AF) is the most common sustained arrhythmia and affects at least $1 \%$ of the population, amounting to 5.5 to 7 million patients with AF in Europe $[1,2]$. AF is characterized by very rapid, irregular electrical activation of the atria (350 to $400 \mathrm{bpm}$ ), resulting in 1) loss of coordinated contraction and transport function in the atria and 2) irregular ventricular rate and loss of ventricular rate adaptation to increased demands (arrhythmia absoluta). In an ageing population, the prevalence and incidence of AF will increase dramatically in the next decades [2,3]. Unlike most other supraventricular tachyarrhythmias, atrial fibrillation can usually not be cured
$[4,5]$. Rather, most patients progress from paroxysmal AF, that is, AF that alternates with periods of sinus rhythm, to sustained forms (Figure 1), even when currently available therapeutic options are applied. This sobering finding is aggravated by the dramatic consequences that AF implies in affected individuals and for society (Table 1).

One of the reasons why AF is so difficult to cure is probably the complex etiology of the arrhythmia as recently outlined in two consensus conferences on AF [6,7]: AF can be caused by atrial structural damage conferred by cardiac or extracardiac disease and rapid irregular ventricular rate $[8,9]$, a sign of natural ageing of the heart, and an electrical 
Table I: Consequences of AF in affected individuals.

\begin{tabular}{|c|c|}
\hline Death & $\begin{array}{l}\text { death rates are doubled in AF patients. This effect is independent of known other cardiovascular risk factors or } \\
\text { concomitant disease. Death rates are also increased in patients with a myocardial infarction or in heart failure patients } \\
\text { when AF is added to their disease pattern. }\end{array}$ \\
\hline Stroke & $\begin{array}{l}\text { Approximately every } 4^{\text {th }} \text { stroke is due to AF. The possibility of "silent", undiagnosed AF - which is common in trials using } \\
\text { systematic ECG monitoring -, may suggest that AF is also a potential cause of "cryptogenic" stroke. }\end{array}$ \\
\hline Quality of life & $\begin{array}{l}\text { is markedly reduced in AF patients, due to their symptoms but possibly also due to an unrecognized effect of } A F \text { on } \\
\text { social functioning, cerebral function, or other factors. It is conceivable that AF-related hospitalizations contribute to } \\
\text { reduced quality of life in AF patients. }\end{array}$ \\
\hline Rhythm & $\begin{array}{l}\text { AF causes arrhythmia absoluta and impairs rate adaptation of heart beat to demand. Abnormal heart rate can cause } \\
\text { symptoms ranging from palpitations to acute chest pain or cardiac decompensation, especially when ventricular rate is } \\
\text { inadequate. }\end{array}$ \\
\hline Left ventricular function & $\begin{array}{l}\text { is impaired by AF, especially in patients with known heart failure or with a tendency to develop heart failure. Restoring } \\
\text { sinus rhythm and maintaining effective heart rate control can prevent such AF-induced decline of heart failure. }\end{array}$ \\
\hline
\end{tabular}

Other relevant outcomes in AF are indicated in $[6,13]$.

accident due to abnormal electrical function of the heart. Furthermore, AF perpetuates itself by altering electrical function of the atria (Figure 2). Unfortunately, all of these mechanisms form vicious circles and are severely aggravated once AF has manifested. Usually, several of these factors have to concur before the arrhythmia develops.

\section{Current management of AF patients}

Adequate therapy of patients with AF considers stroke risk, often requiring continuous oral anticoagulation [4,10-12], AF-related symptoms as, for example, estimated by the European Heart Rhythm Association (EHRA) score [13], ventricular rate during AF, and the risk for AF-related complications [4]. In addition, all conditions that can contribute to AF and to AF-related complications require adequate management [14]. On top of these therapeutic interventions, rhythm control therapy should be considered when AF-related symptoms are severe. The decision for rhythm control is based on individual preferences of the patient and often also considers the perceived risk of AF recurrences [4,5,15-17].

\section{Potential benefits of sinus rhythm}

Potentially, sinus rhythm should be able to prevent the adverse outcomes of AF: In cohort studies, AF associates with death and stroke in the population [1], and AF associates with worse prognosis than sinus rhythm in the setting of an acute myocardial infarction [18] or in patients with heart failure [19-21]. The recently published ATHENA trial also supports this notion by showing that dronedarone, an antiarrhythmic drug with additional rateslowing properties, prevents a composite outcome of cardiovascular hospitalizations and death [22].

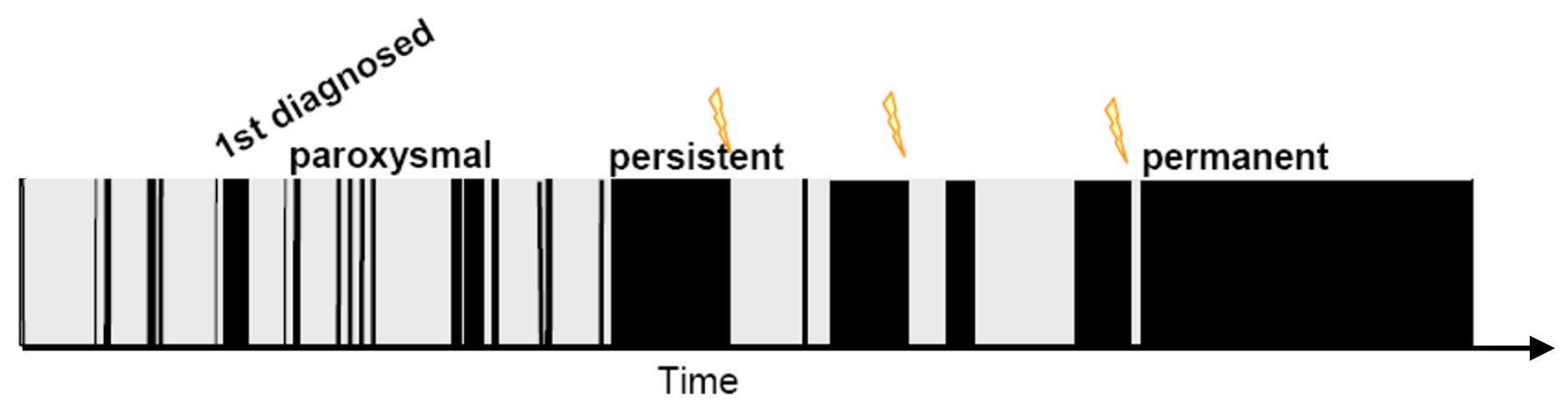

Figure I

Natural time course of atrial fibrillation. Shown is a typical chaotic pattern of time in atrial fibrillation (black) and time in sinus rhythm (grey) over time (x-axis). Atrial fibrillation progresses from undiagnosed to first diagnosed, paroxysmal, persistent, to permanent. Flashes indicate cardioversions as examples for therapeutic interventions that influence the natural time course of the arrhythmia. Reproduced with permission from [13]. 


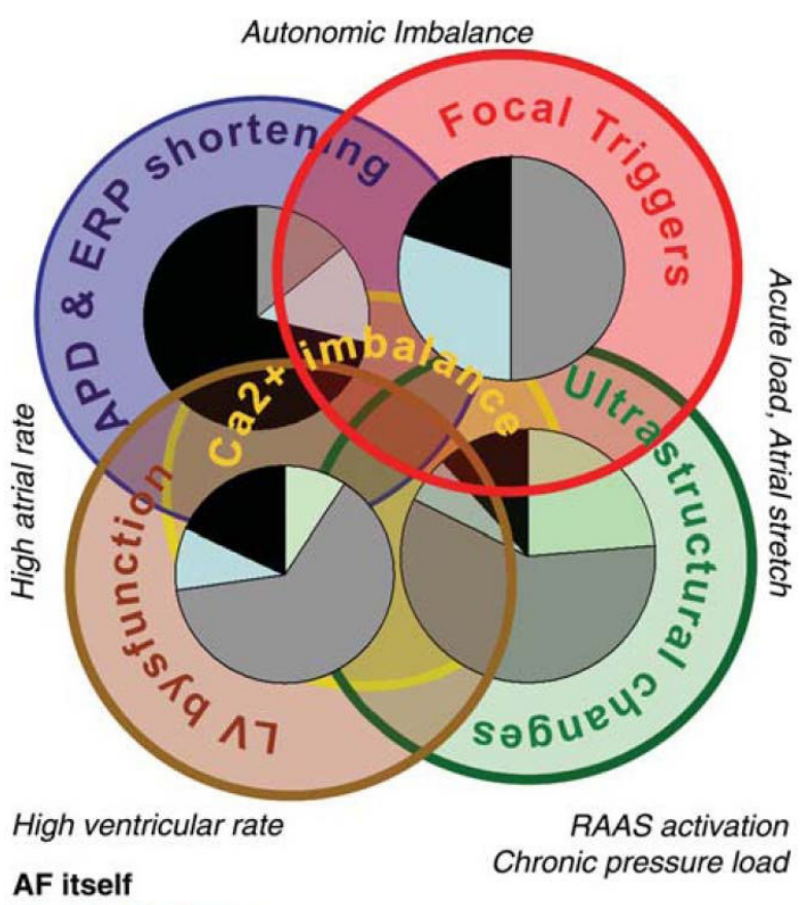

Adaptation to external stressors / diseases Ageing

\section{Figure 2}

Interdependence of four of the main mechanisms that contribute to the initiation and maintenance of atrial fibrillation. Each circle represents a relevant factor that may initiate or perpetuate atrial fibrillation (AF): The blue circle represents shortening of the atrial action potential and effective refractory period (electrical remodelling), the red circle focal triggers of $A F$, the blue circle ultrastructural changes conferred by AF (structural remodelling), and the brown circle the bidirectional damage conferred by left ventricular and (left) atrial function during AF. The pie chart within each circle gives educated guesses as to how often this pathophysiological mechanism will be due to AF itself (black pie piece), genetic predispositions (light blue), a response of the atria to stressors such as hypertension, diabetes, or valvular heart disease (grey), and ageing (light green). In an individual patient (but also in a specific experimental model), AF will be due to a blend of these different factors as indicated by the blended overlap between the circles. Reproduced with permission from [6].

These observations have spurred several controlled trials testing whether rhythm control therapy improves outcomes in AF patients when compared to rate control therapy: At least six controlled trials have been completed and published [17,23-27]. None of these trials showed an advantage of rhythm control over rate control, and a meta analysis even suggested a slight benefit of rate control therapy [28].

\section{Why does rhythm control therapy not translate into better} outcomes?

Several issues warrant consideration in the struggle to explain this unexpected finding.

1. The therapies applied in the published trials were not effective enough to really maintain sinus rhythm: In the large Atrial Fibrillation Follow-up Investigation of Rhythm Management (AFFIRM) trial, sinus rhythm rate was $60 \%$ in the rhythm control group at the end of followup, and 30\% in the rate control group [24]. In the more recent Atrial Fibrillation and Congestive Heart Failure (AF-CHF) trial, sinus rhythm rates were around $60 \%$ in the rhythm control group and $25 \%$ in the rate control group during follow-up [17].

2. Antiarrhythmic drugs, especially when used as longterm therapy, carry a risk of proarrhythmia.

3. Apparent presence of sinus rhythm may have triggered withdrawal of prognostic therapy, for example, antithrombotic therapy, despite the fact that AF may recur silently and cause severe complications.

4. Antiarrhythmic drugs only target one of the mechanisms that cause AF (blue circle in Figure 2). Catheter ablation of AF mainly eliminates focal triggers of AF (red circle in Figure 2). A combination therapy antiarrhythmic drugs and AF ablation procedures has not been tested, let alone a comprehensive therapy including management of other cardiac disease.

5. Many patients were enrolled in the published trials at an advanced stage of AF, often with a long AF history.

\section{Can early therapy of AF help to improve efficacy and safety of rhythm control therapy?}

Atrial fibrillation sustains itself through a complex process that is initiated by high atrial rate, cytosolic calcium overload, metabolic depletion, contractile dysfunction, and counter-regulatory processes that attempt to maintain function of the myocardial cells [6]. When AF is maintained for short periods of time only (minutes to hours), these processes can be reversed by restoring sinus rhythm. After several days or even weeks of the arrhythmia, irreversible atrial damage already develops. Early restoration and maintenance of sinus rhythm could prevent such irreversible AF-induced atrial damage.

Clinical observations support this concept: Conversion of AF to sinus rhythm by antiarrhythmic drugs is relatively effective when AF duration is short [29,30], but almost never effective when AF duration exceeds two weeks [4]. On a similar line, catheter ablation has a higher success 
rate in patients with paroxysmal AF compared to patients with sustained forms of the arrhythmia [31]. Hence, rhythm control therapy may become more effective when it is initiated early [32].

\section{Can earlier diagnosis of AF help to prevent AF-related complications?}

It is very likely that, in addition to the patients with known AF, a large number of additional patients suffer from undiagnosed, silent AF [13]. An active search for AF in patients at risk for the arrhythmia may allow diagnosis of silent AF before the first complication occurs [33,34]. While conventional Holter electrocardiogram (ECG) recordings have a low diagnostic yield for paroxysmal AF, newer technologies like patient-operated or telemetric ECG systems, long-term Holter monitors, or even implanted ECG monitors carry the promise of allowing an early diagnosis of silent AF [6,35-37]. Early diagnosis of AF would not only allow the early initiation of rate and rhythm control therapy, but could also help to prevent AF-related complications, for example, by timely initiation of antithrombotic therapy.

\section{Can rhythm control therapy be delivered safely?}

Early therapy of AF, especially therapy aiming at preventing complications rather than alleviating symptoms, needs to be reasonably safe, and actually safer than therapy that is demanded by a suffering patient. Safety has, however, been a major consideration in antiarrhythmic drug therapy [38]. One example is the AFFIRM trial population in which presence of sinus rhythm during followup associated with better survival, while therapy with antiarrhythmic drugs associated with earlier death [39]. One potential way to resolve this difficulty is to limit antiarrhythmic drug therapies to periods when their effects are really needed [40-42]. Another perspective may be to develop new, safer antiarrhythmic agents [22]. At present, the safety profile of catheter ablation of $\mathrm{AF}$ in relation to its efficacy has not been clearly delineated: Success rates are high, especially in paroxysmal AF patients, but complication rates are not negligible [43-45], and although most complications can be managed without long-term sequelae, there is a residual death rate induced by AF ablation [45].

\section{Summary}

Although atrial fibrillation is clearly associated with severe consequences such as stroke, heart failure, and death, current rhythm management in AF patients does not translate into improved outcomes. Earlier initiation of rhythm control therapy, especially when embedded in a comprehensive AF management strategy, has the potential to maintain sinus rhythm more effectively, to disrupt the vicious circles that maintain $\mathrm{AF}$ and cause its complications, and to prevent AF-related complications before they occur. Potentially, a combination of intermittent, shortterm antiarrhythmic drug therapy, antiarrhythmic drug therapy using new, potentially safer agents, and catheter ablation of AF could be components of early rhythm control therapy. Given the potential benefits and risk of such a therapy, there is a clear need to test whether early rhythm control therapy of AF can improve outcomes in AF patients.

\section{Competing interests}

I have received consulting fees or honoraria from $3 \mathrm{M}$ Medica, ASTRAZENECA, Bayer Healthcare, Boehringer Ingelheim, MEDA Pharma, Medtronic, SANOFI-Aventis, Servier, Siemens, TAKEDA. I have received research grants from Medtronic, OMRON, St Jude Medical, the German Federal Ministry for Education and Research (BMBF), Fondation LeDucq, and the German Resarch Foundation (DFG). I am or have been principle Principal Investigator of the following trials: APAL; MOBIPAPA; Flec-SL. I am member of the steering committee of the BMBF-funded AFNET and member of the board of EHRA.

\section{Acknowledgements}

This work was supported by AFNET and Fondation LeDucq. The concept of early and comprehensive therapy of AF was discussed in detail during the $2^{\text {nd }}$ AFNET/EHRA consensus conference organized by AFNET and EHRA [6]. The discussions during and after that conference clearly influenced the ideas expressed here.

\section{References}

I. Benjamin EJ, Wolf PA, D'Agostino RB, Silbershatz H, Kannel WB, Levy $\mathrm{D}$ : Impact of atrial fibrillation on the risk of death: the Framingham Heart Study. Circulation 1998, 98:946-952.

2. Stewart S, Hart CL, Hole DJ, McMurray J): A population-based study of the long-term risks associated with atrial fibrillation: 20-year follow-up of the Renfrew/Paisley study. Am J Med 2002, I I 3:359-364.

3. Miyasaka Y, Barnes ME, Gersh BJ, Cha SS, Bailey KR, Abhayaratna WP, Seward JB, Tsang TS: Secular Trends in Incidence of Atrial Fibrillation in Olmsted County, Minnesota, 1980 to 2000, and Implications on the Projections for Future Prevalence. Circulation 2006, I | 4: I I9-I25.

4. Fuster V, Ryden LE, Cannom DS, Crijns HJ, Curtis AB, Ellenbogen KA, Halperin JL, Le Heuzey JY, Kay GN, Lowe JE, Olsson SB, Prystowsky EN, Tamargo JL, Wann S, Smith SC Jr, Jacobs AK, Adams CD, Anderson JL, Antman EM, Halperin JL, Hunt SA, Nishimura R, Ornato JP, Page RL, Riegel B, Priori SG, Blanc J], Budaj A, Camm AJ, Dean V, et al.: ACC/AHA/ESC 2006 guidelines for the management of patients with atrial fibrillation: full text: A report of the American College of Cardiology/American Heart Association Task Force on practice guidelines and the European Society of Cardiology Committee for Practice Guidelines (Writing Committee to Revise the 200I Guidelines for the Management of Patients With Atrial Fibrillation) Developed in collaboration with the European Heart Rhythm Association and the Heart Rhythm Society. Europace 2006, 8:65I-745.

5. Calkins H, Brugada J, Packer DL, Cappato R, Chen SA, Crijns HJ, Damiano RJ Jr, Davies DW, Haines DE, Haissaguerre M, lesaka $Y$, Jackman W, Jais P, Kottkamp H, Kuck KH, Lindsay BD, Marchlinski FE, McCarthy PM, Mont JL, Morady F, Nademanee K, Natale A, Pappone C, Prystowsky E, Raviele A, Ruskin JN, Shemin RJ, Calkins H, Brugada J, Chen SA, et al.: HRS/EHRA/ECAS Expert Consensus Statement on Catheter and Surgical Ablation of Atrial Fibrillation: Recommendations for Personnel, Policy, Procedures and Follow-Up: A report of the Heart Rhythm Society (HRS) Task Force on Catheter and Surgical Ablation of Atrial 
Fibrillation Developed in partnership with the European Heart Rhythm Association (EHRA) and the European Cardiac Arrhythmia Society (ECAS); in collaboration with the American College of Cardiology (ACC), American Heart Association (AHA), and the Society of Thoracic Surgeons (STS). Endorsed and Approved by the governing bodies of the American College of Cardiology, the American Heart Association, the European Cardiac Arrhythmia Society, the European Heart Rhythm Association, the Society of Thoracic Surgeons, and the Heart Rhythm Society. Europace 2007, 9:335-379.

6. Kirchhof $\mathrm{P}, \mathrm{Bax}$, Blomstrom-Lundquist $\mathrm{C}$, Calkins H, Camm AJ, Cappato R, Cosio F, Crijns H, Diener HC, Goette A, Israel CW, Kuck KH, Lip GY, Nattel S, Page RL, Ravens U, Schotten U, Steinbeck G, Vardas P, Waldo A, Wegscheider K, Willems S, Breithardt G: Early and comprehensive management of atrial fibrillation: Proceedings from the 2 nd AFNET/EHRA consensus conference on atrial fibrillation entitled 'research perspectives in atrial fibrillation'. Europace 2009, I I:860-85.

7. Benjamin EJ, Chen PS, Bild DE, Mascette AM, Albert CM, Alonso A, Calkins H, Connolly SJ, Curtis AB, Darbar D, Ellinor PT, Go AS, Goldschlager NF, Heckbert SR, Jalife J, Kerr CR, Levy D, Lloyd-Jones DM, Massie BM, Nattel S, Olgin JE, Packer DL, Po SS, Tsang TS, Van Wagoner DR, Waldo AL, Wyse DG: Prevention of atrial fibrillation: report from a national heart, lung, and blood institute workshop. Circulation 2009, I 1 9:606-6/8.

8. Kannel WB, Wolf PA, Benjamin EJ, Levy D: Prevalence, incidence, prognosis, and predisposing conditions for atrial fibrillation: population-based estimates. Am J Cardiol 1998, 82:2N-9N.

9. Curtis AB, Gersh BJ, Corley SD, DiMarco JP, Domanski MJ, Geller N, Greene HL, Kellen JC, Mickel M, Nelson JD, Rosenberg Y, Schron E, Shemanski L, Waldo AL, Wyse DG: Clinical factors that influence response to treatment strategies in atrial fibrillation: the Atrial Fibrillation Follow-up Investigation of Rhythm Management (AFFIRM) study. Am Heart J 2005, 1 49:645-649.

10. Hylek EM, Go AS, Chang Y, Jensvold NG, Henault LE, Selby JV, Singer $D E$ : Effect of intensity of oral anticoagulation on stroke severity and mortality in atrial fibrillation. N Engl J Med 2003, 349:1019-1026.

II. Mant J, Hobbs FD, Fletcher K, Roalfe A, Fitzmaurice D, Lip GY, Murray $E$ : Warfarin versus aspirin for stroke prevention in an elderly community population with atrial fibrillation (the Birmingham Atrial Fibrillation Treatment of the Aged Study, BAFTA): a randomised controlled trial. Lancet 2007, 370:493-503.

12. Connolly SJ, Ezekowitz MD, Yusuf S, Eikelboom J, Oldgren J, Parekh A, Pogue J, Reilly PA, Themeles E, Varrone J, Wang S, Alings M, Xavier $D$, Zhu J, Diaz R, Lewis BS, Darius H, Diener HC, Joyner CD, Wallentin L: Dabigatran versus warfarin in patients with atrial fibrillation. N Engl J Med 2009, 36 I: I I39-I I5I.

13. Kirchhof $\mathrm{P}$, Auricchio A, Bax J, Crijns H, Camm J, Diener HC, Goette A, Hindricks G, Hohnloser S, Kappenberger L, Kuck KH, Lip GY, Olsson B, Meinertz T, Priori S, Ravens U, Steinbeck G, Svernhage E, Tijssen J, Vincent A, Breithardt G: Outcome parameters for trials in atrial fibrillation: Recommendations from a consensus conference organized by the German Atrial Fibrillation Competence NETwork and the European Heart Rhythm Association. Europace 2007, 9:1006-1023.

14. Healey JS, Baranchuk A, Crystal E, Morillo CA, Garfinkle M, Yusuf S, Connolly SJ: Prevention of atrial fibrillation with angiotensinconverting enzyme inhibitors and angiotensin receptor blockers: a meta-analysis. J Am Coll Cardiol 2005, 45: I832-I839.

15. Nattel S, Opie LH: Controversies in atrial fibrillation. Lancet 2006, 367:262-272.

16. Kirchhof P, Auricchio A, Bax J, Crijns H, Camm J, Diener HC, Goette A, Hindricks G, Hohnloser S, Kappenberger L, Kuck KH, Lip GY, Olsson B, Meinertz T, Priori S, Ravens U, Steinbeck G, Svernhage E, Tijssen J, Vincent A, Breithardt G: Outcome parameters for trials in atrial fibrillation: executive summary: Recommendations from a consensus conference organized by the German Atrial Fibrillation Competence NETwork (AFNET) and the European Heart Rhythm Association (EHRA). Eur Heart J 2007, 28:2803-28I7.

17. Roy D, Talajic M, Nattel S, Wyse DG, Dorian P, Lee KL, Bourassa MG, Arnold JM, Buxton AE, Camm AJ, Connolly SJ, Dubuc M, Ducharme A, Guerra PG, Hohnloser SH, Lambert J, Le Heuzey JY, O'Hara
G, Pedersen OD, Rouleau JL, Singh BN, Stevenson LW, Stevenson WG, Thibault B, Waldo AL: Rhythm control versus rate control for atrial fibrillation and heart failure. N Engl J Med 2008, 358:2667-2677.

18. Schmitt J, Duray G, Gersh BJ, Hohnloser SH: Atrial fibrillation in acute myocardial infarction: a systematic review of the incidence, clinical features and prognostic implications. Eur Heart J 2009, 30:1038-1045.

19. Pedersen OD, Sondergaard P, Nielsen T, Nielsen SJ, Nielsen ES, Falstie-Jensen N, Nielsen I, Kober L, Burchardt H, Seibaek M, Torp-Pedersen C: Atrial fibrillation, ischaemic heart disease, and the risk of death in patients with heart failure. Eur Heart J 2006, 27:2866-2870.

20. Rivero-Ayerza M, Scholte Op Reimer W, Lenzen M, Theuns DA, Jordaens L, Komajda M, Follath F, Swedberg K, Cleland JG: New-onset atrial fibrillation is an independent predictor of in-hospital mortality in hospitalized heart failure patients: results of the EuroHeart Failure Survey. Eur Heart J 2008, 29: 16I8-I624.

21. Dries DL, Exner DV, Gersh BJ, Domanski MJ, Waclawiw MA, Stevenson LW: Atrial fibrillation is associated with an increased risk for mortality and heart failure progression in patients with asymptomatic and symptomatic left ventricular systolic dysfunction: a retrospective analysis of the SOLVD trials. Studies of Left Ventricular Dysfunction. J Am Coll Cardiol 1998, 32:695-703

22. Hohnloser SH, Crijns HJ, van Eickels M, Gaudin C, Page RL, TorpPedersen C, Connolly SJ: Effect of dronedarone on cardiovascular events in atrial fibrillation. N Engl J Med 2009, 360:668-678.

23. Hohnloser $\mathrm{SH}$, Kuck KH, Lilienthal J: Rhythm or rate control in atrial fibrillation--Pharmacological Intervention in Atrial Fibrillation (PIAF): a randomised trial. Lancet 2000, 356:1789-1794

24. AFFIRM I: A comparison of rate control and rhythm control in patients with atrial fibrillation. N Engl J Med 2002, 347:1825-1833

25. Van Gelder I, Hagens VE, Bosker HA, Kingma H, Kamp O, Kingma T, Said SA, Darmanata JI, Timmermanns AJM, Tijssen JGP, Crijns HJ: A comparison of rate control and rhythm control in patients with recurrent persistent atrial fibrillation. N Engl J Med 2002, 347: $1834-1840$

26. Carlsson J, Miketic S, Windeler J, Cuneo A, Haun S, Micus S, Walter $S$, Tebbe $U$, Investigators $S$ : Randomzied trial of rate-control versus rhythm-control in persistent atrial fibrillation. J Am Coll Cardiol 2003, 41:1690-1696.

27. Opolski G, Torbicki A, Kosior DA, Szulc M, Wozakowska-Kaplon B, Kolodziej $P$, Achremczyk $P$ : Rate control vs rhythm control in patients with nonvalvular persistent atrial fibrillation: the results of the Polish How to Treat Chronic Atrial Fibrillation (HOT CAFE) Study. Chest 2004, I 26:476-486.

28. Testa L, Biondi-Zoccai GG, Dello Russo A, Bellocci F, Andreotti F, Crea F: Rate-control vs. rhythm-control in patients with atrial fibrillation: a meta-analysis. Eur Heart J 2005, 26:2000-2006.

29. Roy D, Pratt CM, Torp-Pedersen C, Wyse DG, Toft E, Juul-Moller S, Nielsen T, Rasmussen SL, Stiell IG, Coutu B, Ip JH, Pritchett EL, Camm AJ: Vernakalant hydrochloride for rapid conversion of atrial fibrillation: a phase 3, randomized, placebo-controlled trial. Circulation 2008, II 7:1518-1525.

30. Oral H, Souza JJ, Michaud GF, Knight BP, Goyal R, Strickberger SA, Morady F: Facilitating transthoracic cardioversion of atrial fibrillation with ibutilide pretreatment. N Engl J Med 1999, 340:1849-1854

3I. Calkins H, Reynolds MR, Spector P, Sondhi M, Xu Y, Martin A, Williams CJ, Sledge I: Treatment of atrial fibrillation with antiarrhythmic drugs or radiofrequency ablation: two systematic literature reviews and meta-analyses. Circ Arrhythm Electrophysiol 2009, 2:349-36I.

32. Cosio FG, Aliot E, Botto GL, Heidbuchel H, Geller CJ, Kirchhof P, De Haro JC, Frank R, Villacastin JP, Vijgen J, Crijns H: Delayed rhythm control of atrial fibrillation may be a cause of failure to prevent recurrences: reasons for change to active antiarrhythmic treatment at the time of the first detected episode. Europace 2008, 10:21-27.

33. Jabaudon D, Sztajzel J, Sievert K, Landis T, Sztajzel R: Usefulness of ambulatory 7-day ECG monitoring for the detection of atrial fibrillation and flutter after acute stroke and transient ischemic attack. Stroke 2004, 35: 1647-I65I. 
34. Liao J, Khalid Z, Scallan C, Morillo C, O'Donnell M: Noninvasive cardiac monitoring for detecting paroxysmal atrial fibrillation or flutter after acute ischemic stroke: a systematic review. Stroke 2007, 38:2935-2940.

35. Kaleschke G, Hoffmann B, Drewitz I, Steinbeck G, Naebauer M, Goette A, Breithardt G, Kirchhof P: Prospective, multicentre validation of a simple, patient-operated electrocardiographic system for the detection of arrhythmias and electrocardiographic changes. Europace 2009, I I:I362-I368.

36. Piorkowski C, Kottkamp H, Tanner H, Kobza R, Nielsen JC, Arya A, Hindricks G: Value of different follow-up strategies to assess the efficacy of circumferential pulmonary vein ablation for the curative treatment of atrial fibrillation. J Cardiovasc Electrophysiol 2005, 16:1286-1292.

37. Brignole M, Vardas P, Hoffman E, Huikuri H, Moya A, Ricci R, Sulke N, Wieling W, Auricchio A, Lip GY, Almendral J, Kirchhof P, Aliot E, Gasparini M, Braunschweig F, Botto GL: Indications for the use of diagnostic implantable and external ECG loop recorders. Europace 2009, II I:67I-687.

38. Lafuente-Lafuente C, Mouly S, Longas-Tejero MA, Mahe I, Bergmann $\mathrm{JF}$ : Antiarrhythmic drugs for maintaining sinus rhythm after cardioversion of atrial fibrillation: a systematic review of randomized controlled trials. Arch Intern Med 2006, 166:719-728.

39. Corley SD, Epstein AE, DiMarco JP, Domanski MJ, Geller N, Greene $H L$, Josephson RA, Kellen JC, Klein RC, Krahn AD, Mickel M, Mitchell LB, Nelson JD, Rosenberg Y, Schron E, Shemanski L, Waldo AL, Wyse DG: Relationships between sinus rhythm, treatment, and survival in the Atrial Fibrillation Follow-Up Investigation of Rhythm Management (AFFIRM) Study. Circulation 2004, 109:1509-1513.

40. Kirchhof $P$, Breithardt G: New concepts for old drugs to maintain sinus rhythm in patients with atrial fibrillation. Heart Rhythm 2007, 4:790-793.

4l. Alboni P, Botto GL, Baldi N, Luzi M, Russo V, Gianfranchi L, Marchi P, Calzolari M, Solano A, Baroffio R, Gaggioli G: Outpatient treatment of recent-onset atrial fibrillation with the "pill-in-thepocket" approach. N Engl J Med 2004, 35 I:2384-239I.

42. Kirchhof P, Fetsch T, Hanrath P, Meinertz T, Steinbeck G, Lehmacher W, Breithardt G: Targeted pharmacological reversal of electrical remodeling after cardioversion--rationale and design of the Flecainide Short-Long (Flec-SL) trial. Am Heart J 2005, I 50(899): el-e6.

43. Cappato R, Calkins H, Chen SA, Davies W, lesaka Y, Kalman J, Kim $\mathrm{YH}$, Klein G, Packer D, Skanes A: Worldwide survey on the methods, efficacy, and safety of catheter ablation for human atrial fibrillation. Circulation 2005, I I I: I I00- I I05.

44. Fisher JD, Spinelli MA, Mookherjee D, Krumerman AK, Palma EC: Atrial fibrillation ablation: reaching the mainstream. Pacing Clin Electrophysiol 2006, 29:523-537.

45. Cappato R, Calkins H, Chen SA, Davies W, lesaka Y, Kalman J, Kim YH, Klein G, Natale A, Packer D, Skanes A: Prevalence and causes of fatal outcome in catheter ablation of atrial fibrillation. J Am Coll Cardiol 2009, 53:1798-1803.

\section{Pre-publication history}

The pre-publication history for this paper can be accessed here:

http://www.biomedcentral.com/1741-7015/7/72/prepub 